\section{Disappointing Interim Palæomagnetic Results from the Seychelles}

RECENT seismic refraction experiments mado in connoxion with the International Indian Ocean Expedition have confirmed that the shallow Seychelles Bank has crustal structure of a continental type and represents an isolated continental fragment in the middle of the northwest Indian Ocean ${ }^{1,2}$. The late Precambrian granites exposed on the central islands of the Seychelles group have been shown to be cut by two sets of dolerite dykes which are of a Precambrian and early Tertiary age, respectively ${ }^{3,4}$.

Du Toit and other writers have suggested that the Soychelles represent a fragment left behind during the break-up of Gondwanaland ${ }^{5}$, and it is clear that this hypothesis is now in need of testing. Accordingly, in Novomber 1963 (ref. 2) we collocted 71 orientated specimens from 40 different dykes, sampling all the more accessible dykes shown on Mr. B. H. Baker's geological map ${ }^{4}$ on the islands of Mahé, Praslin, Cousin, La Digne, Felicité and Marianne. The natural remanent magnetization directions of these specimens have been measured by one of us (T. A. R.) using an astatic magnetometer in Nairobi. The results are widely scattered and strongly suggest that the rocks are unstable. It is to be hoped that the a.c. domagnetization and thermal 'washing' tochniques, which are now being tried, will reveal a significant grouping of the magnetic vectors.

This disappointing preliminary result would certainly not warrant publication in the normal course of events. However, the Seychelles are of current interest in connoxion with the International Indian Ocean Expedition, and as this experiment is a particularly obvious one, we imagine that other groups are likely to consider going to these remote islands to collect palæomagnetic material. We wish them better luck than we have had.

Department of Geodesy and Geophysics,

$$
\text { D. H. MatThews }
$$

University of Cambridge.

Department of Physics,

\section{T. A. REILIY} University College, Nairobi.

${ }^{t}$ Davies, D., and Francis, T. J. G., Deep Sea Res. (in the press). ${ }^{2}$ Royal Society, International Indian Ocean Expedition R.R.S. Discovery Cruise 2 Rep., London (1964).

${ }^{3}$ Baker, B. H., and Miller, J. A., Nature, 199, 346 (1963).

- Baker, B. H., Geological Survey of Kenya, Mem. No. 3 (1963).

${ }^{5}$ Du Toit, A., Our Wandering Continents, 125 (1937).

\section{Heights of Central Absorbing Regions for a Strong Auroral Absorption Event at Lower Latitude}

Abnormal ionospheric absorption of cosmic radio noise has been investigated at Moscow $\left(46^{\circ} 44^{\prime} \mathrm{N} ., 117^{\circ}\right.$ $00^{\prime}$ W.), Idaho, U.S.A., since September 1962. Observations are being made by three riometers operating at the frequencies of 20,30 and $40 \cdot 25 \mathrm{Mc} / \mathrm{s}$.

The majority of abnormal absorption events obtained occurred prior to the International Years of the Quiet Sun. Five types of absorption were positively identified. They are sudden commencement absorption, sudden cosmic noise absorption, auroral absorption, sunset absorption and sunrise absorption.

One phase of the investigations included hoight determinations of tho central absorbing regions for a strong auroral absorption event at lower latitude. This communi-

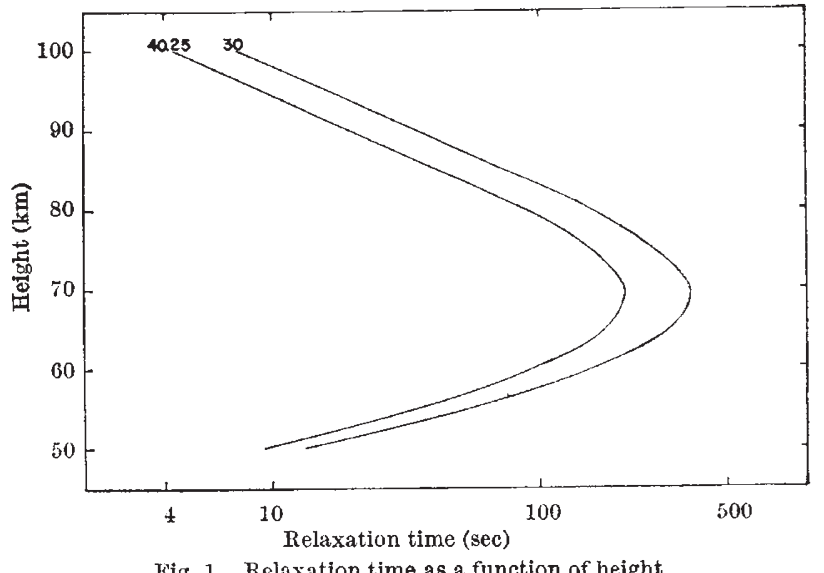

Fig. 1. Relaxation time as a function of height

cation reports the heights of central absorbing regions for the strong auroral absorption events of September 22, 1963, which were deduced by utilizing the relaxation time method introduced by Ziauddin ${ }^{1}$. This method relies on the fact that the absorption (expressed in db) suffered by a radio wave in the lower ionosphere is proportional to the number of electrons encountered in the absorbing region and is a function of the collisional frequency of the electrons.

The electronic collisional frequencies, $v$ at various heights, were calculated from the following formula given by Nicolet ${ }^{2}$ :

$$
\nu=5.4 \times 10^{-10} n T^{1 / 2}
$$

Height distributions of $n$ (number density of the atmospheric constituents) and $T$ (atmospheric temperature) were adopted from the U.S. Standard Atmosphere, 1962 (ref. 3), which is an idealized, middle-latitude yearround mean over the range of solar activity between sunspot minimum and maximum. The calculated values of $\nu$ are given in Table 1.

Following Ziauddin's assumptions, the effective electron densities at various heights for the observing frequencies of $30 \mathrm{Mc} / \mathrm{s}$ and $40.25 \mathrm{Mc} / \mathrm{s}$ were determined from the following well-known equation:

$$
A(\mathrm{db})=0.46 \int \frac{N \nu}{\left(w+w_{2}\right)^{2}+\nu^{2}} \mathrm{~d} S
$$

The symbols used in equation (2) have usual meanings.

The effectivo olectron densities at various heights were then combined with the corresponding recombination rates $\alpha$ given by Moler $^{4}$ to calculate the ionospheric relaxation times $(T=1 / 2 \alpha N$ sec) at various heights. The calculated relaxation times were plotted as a function of height in Fig. 1. Figs. 2 and 3 respectively show simultaneous strong auroral absorption events of September 22, 1963 ( $120^{\circ}$ W.M.T.), observed at the frequencies of 30 $\mathrm{Mc} / \mathrm{s}$ and $40.25 \mathrm{Mc} / \mathrm{s}$. Heights deduced from Fig. 1 for $30 \mathrm{Mc} / \mathrm{s}$ events are in the range of $79-86 \mathrm{~km}$, while for $40.25 \mathrm{Mc} / \mathrm{s}$ they are in the range of $72-78 \mathrm{~km}$. The 40.25 $\mathrm{Mc} / \mathrm{s}$ waves were absorbed at lower heights than the $30 \mathrm{Mc} / \mathrm{s}$ waves as predicted by magnetoionic theory. For $30 \mathrm{Mc} / \mathrm{s}$ events, heights of central absorbing regions are somewhat higher than those reported at higher latitudes ${ }^{5}$. For both 30 and $40 \cdot 25 \mathrm{Mc} / \mathrm{s}$ events, there was a tendency for successive absorption onsets to progress toward lower heights. Ziauddin and Forsyth ${ }^{5}$ also found a similar tendency.

It should be noted that the relaxation-time method is

\begin{tabular}{|c|c|c|c|c|c|c|c|c|c|c|c|}
\hline$\underset{v\left(\mathrm{sec}^{-1}\right)}{\text { Height }}(\mathrm{km})$ & $\begin{array}{c}50 \\
1 \cdot 90^{8 *}\end{array}$ & $\begin{array}{c}55 \\
1 \cdot 03^{8}\end{array}$ & $\begin{array}{c}60 \\
5 \cdot 48^{7}\end{array}$ & $\begin{array}{c}65 \\
2 \cdot 90^{7}\end{array}$ & $\begin{array}{c}70 \\
\boldsymbol{x} \cdot 45^{7}\end{array}$ & $\begin{array}{c}75 \\
6.91^{\circ}\end{array}$ & $\begin{array}{c}80 \\
\mathbf{3} \cdot 01^{\circ}\end{array}$ & $\begin{array}{c}85 \\
1 \cdot 10^{8}\end{array}$ & $\begin{array}{c}90 \\
4 \cdot 77^{5}\end{array}$ & $\begin{array}{l}95 \\
1.91^{5}\end{array}$ & $\begin{array}{l}100 \\
8 \cdot 14^{4}\end{array}$ \\
\hline
\end{tabular}
subject to certain criticisms, but for a first approximation

Table 1. THE ELECTRON COLLISIONAL Frequency

* The form of $N \times 10^{m}$ is given in the form of $\mathrm{N}^{\mathrm{m}}$. 